\title{
The hospital designed by hospitalized children and adolescents
}

\author{
O hospital arquitetado por crianças e adolescentes hospitalizados \\ El hospital diseñado por niños y adolescentes internados
}

Larissa Karoline Dias da Silva Cassemiro'

ORCID: 0000-0001-6825-8022

Aline Cristiane Cavicchioli Okido"

ORCID: 0000-0003-4309-5612

Maria Cândida de Carvalho Furtado'

ORCID: 0000-0001-7942-4110

Regina Aparecida Garcia de Lima' ORCID: 0000-0002-0611-5621

'Universidade de São Paulo. Ribeirão Preto, São Paulo, Brazil. "Universidade Federal de São Carlos. São Carlos, São Paulo, Brazil.

How to cite this article:

Cassemiro LKDS, Okido ACC, Furtado MCC, Lima RAG. The hospital designed by hospitalized children and adolescents.

Rev Bras Enferm. 2020;73(Suppl 4):e20190399. doi: http://dx.doi.org/10.1590/0034-7167-2019-0399

\section{Corresponding author:}

Larissa Karoline Dias da Silva Cassemiro

E-mail: larissakaroline@usp.br

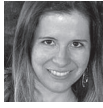

EDITOR IN CHIEF: Antonio José de Almeida Filho ASSOCIATE EDITOR: Andrea Bernardes

Submission: 08-15-2019

Approval: 06-26-2020

\section{ABSTRACT}

Objective: to identify, through the contributions of hospitalized children and adolescents, the characteristics they consider necessary for a hospital that promotes well-being and development. Method: descriptive and exploratory study, with qualitative data analysis, carried out with a total of 30 hospitalized children and adolescents. Data were collected through semi-structured interviews, mediated by drawing, and analyzed by inductive thematic analysis, supported by the theoretical framework of the humanization of health care and the Florence Nightingale's Environmental Theory. Results: the designed hospital takes up the principles of Florence Nightingale's Environmental Theory, as well as one of the guidelines of the National Humanization Policy, the environment, from two perspectives: elements and material resources from the physical environment; elements of comfort and well-being environment. Final considerations: hospitals such as the projected institution corroborate what is recommended in public policies, as they qualify health care.

Descriptors: Child; Adolescent; Hospitalization; Health Institutions Environment; Nursing Care

\section{RESUMO}

Objetivo: identificar, por meio das contribuições de crianças e adolescentes hospitalizados, as características por eles consideradas necessárias a um hospital promotor de bem-estar e desenvolvimento. Método: estudo descritivo e exploratório, com análise qualitativa dos dados, realizado com 30 crianças e adolescentes hospitalizados. Os dados foram coletados por meio de entrevistas semiestruturadas, intermediadas pelo desenho, e tratados mediante análise temática indutiva, sustentada no quadro teórico da humanização do cuidado em saúde e na Teoria Ambientalista de Florence Nightingale. Resultados: o hospital projetado retoma os princípios da Teoria Ambientalista de Florence Nightingale, bem como uma das diretrizes da Política Nacional de Humanização, a ambiência, a partir de duas dimensões: elementos do ambiente físico e recursos materiais e elementos do ambiente de conforto e bem-estar. Considerações finais: hospitais como a instituição projetada corroboram o preconizado nas políticas públicas, pois qualificam o cuidado em saúde.

Descritores: Criança; Adolescente; Hospitalização; Ambiente de Instituições de Saúde Cuidados de Enfermagem.

\section{RESUMEN}

Objetivo: identificar, mediante las aportaciones de niños y adolescentes hospitalizados, las características que consideran necesarias para un hospital de bienestar y desarrollo. Método: Se trata de un estudio descriptivo y exploratorio, con análisis cualitativo de los datos, realizado entre 30 niños y adolescentes hospitalizados. Los datos, apoyados por el marco teórico de la humanización de la atención sanitaria y la Teoría Ambiental de Florence Nightingale, se recogieron con entrevistas semiestructuradas, mediadas por el diseño y tratadas mediante análisis temáticos inductivos. Resultados: el hospital proyectado retoma los principios de la Teoría Ambiental de Florence Nightingale, así como una de las directivas de la Política Nacional de Humanización, la ambientación, a partir de dos dimensiones: elementos del ambiente físico y recursos materiales y elementos del ambiente de confort y bienestar. Consideraciones finales: El hospital, como una institución proyectada, corrobora lo que se recomienda en las políticas públicas, al brindar calidad a la atención sanitaria.

Descriptores: Niño; Adolescente; Hospitalización; Ambiente de Instituciones Sanitarias; Cuidados de Enfermería. 


\section{INTRODUCTION}

In general, hospitals are unfamiliar environments, which have their own routines, equipment and strange people ${ }^{(1-2)}$. In addition, during hospitalization, children and adolescents are distant from friends and family ${ }^{(1-4)}$ and are frequently exposed to painful procedures ${ }^{(1,3-4)}$. Thus, hospitals are often related to negative feelings, such as sadness and fear, characterized as a potentially traumatic ecology ${ }^{(1-4)}$.

In the 19th century, Florence Nightingale, in her first books, Notes on nursing: what it is and what it is not ${ }^{(5)}$, Sick nursing and health nursing ${ }^{(6)}$ and Notes on hospitals ${ }^{(7)}$, already argued that the care environment, the hospital one in this case, could negatively impact the health, emotional and spiritual state of hospitalized people. According to her, some factors could cause discomfort during the hospitalization process: lack of light, hygiene and ventilation; unpleasant odors; beds with sheets wet with sweat or with sheets that had folds causing pressure points on the patients'skin; and environmental noise capable of impairing the hospital patients' need for rest ${ }^{(5)}$.

Based on these observations, and from a different perspective on the environment, Florence proposed that these institutions be designed to meet the individuals' essential needs, which, according to her, would favor the restoration of their health ${ }^{(5,8-9)}$. This is the context that originated Florence Nightingale's Environmental Theory ${ }^{(9)}$, which determines changes in European hospital institutions in order to associate nursing care with elements of the physical environment, such as color variations, adequate ventilation, lighting and noise control ${ }^{(5,9)}$.

Although this theory was presented in the 19th century, its principles remain valid nowadays, as studies have reiterated that the hospital environment can negatively interfere in the hospitalization process, resulting in a potentially traumatic $c^{(1-4,10-11)}$ or non-traumatic ${ }^{(1,12-13)}$ experience. Thus, when this environment allows the establishment of friendships, it promotes well-being, with specific recreational activities according to the age group, it is characterized as a space for healing and also as an element that favors a less painful experience for the patients ${ }^{(1-2)}$.

In favor of a non-traumatic ecology, Nightingale already defended humanized care, based on the adequacy of the space around the individual, seen as someone who has relationships and interactions with the environment ${ }^{(5)}$ and biopsychosocial needs, that need to be met ${ }^{(8)}$.

Thus, the National Humanization Policy (NHP), promulgated in 2003 , reinforced the need to structure the hospital environment in order to contribute to the restoration of the individuals' well-being $^{(14)}$. A structural element of the NHP is the hospital environment, which is divided into three axes. The first one is comfortability, focused on privacy and individuality in order to promote a comfortable and welcoming environment for users and health professionals, through the combination and balance of colors, sounds, lighting and odors, since these elements can act as modifiers and qualifiers of the space, essential in health production. The second axis, production of subjectivities, allows users, workers and managers to use the hospital space to act and reflect on the work process, producing new knowledge. Finally, the third axis, space, is used as a tool to facilitate the work process and aims at building an environment that transcends architecture, promoting the individuals' well-being and health ${ }^{(15)}$.

It has already been proven that the incentives received by the children, especially in their first years of life, are fundamental for the maturity of their brain circuit, as they promote emotional and intellectual development ${ }^{(16)}$. These findings corroborate the Bioecological Theory of Human Development ${ }^{(17)}$, according to which the environment influences the change of individuals' biopsychological characteristics. Therefore, children and adolescents need to live in environments that contribute to the acquisition of skills essential to the development stages, even during hospitalization processes.

Environments that promote recreational activities are strong allies of motor, emotional, mental and social development, in addition to contributing to a less traumatic hospitalization, as they favor coping with the situation, the (re) significance of pathology and acceptance of treatment ${ }^{(18)}$. A qualitative approach study with children aged from 7 to 12 years old under outpatient therapeutic follow-up at a pediatric university hospital in Sao Paulo showed that the therapeutic environment, when designed from the perspective of these patients, allows them to know their preferences, as well as their health and disease conditions and treatment, which makes it less traumatic ${ }^{(19)}$.

Although the construction of hospital environments that promote well-being ${ }^{(14-15,20)}$ and development is present in health policies, the literature still reports the maintenance of worrying adverse effects of hospitalization ${ }^{(1-4)}$. Thus, this study intends to broaden the understanding of this complex and dual phenomenon, that is, the hospital as a place of pain and suffering and, at the same time, a promoter of healing and development, based on the contributions of children and adolescents who experience hospitalization processes and not from the adult-centric perspective, usually analyzed.

\section{OBJECTIVE}

To identify, through the contributions of hospitalized children and adolescents, the characteristics they consider necessary for a hospital that promotes well-being and development.

\section{METHOD}

\section{Ethical aspects}

The study was approved by the Research Ethics Committee of the Nursing School in Ribeirao Preto at the University of Sao Paulo (EERP-USP), in compliance with the guidelines of Resolution $466 / 2012$ of the National Health Council(21) ${ }^{(21}$ The participants were duly informed about the objectives of the study and procedures for data collection and, then, those who agreed to participate signed the Informed Consent Form (guardians) and the assent form (children and adolescents). To ensure anonymity, the interviewees chose their codenames, and in the case of repeated choices, the letters A, B and C were added to differentiate them. The study was developed according to the recommendations for the preparation of qualitative research by COREQ (Consolidated Criteria for Reporting Qualitative Research). 


\section{Type of study}

This is an exploratory, descriptive study, with qualitative data analysis, having as theoretical framework one of the guidelines of the NHP, the environment and Florence Nightingale's environmental theory.

\section{Study scenario}

The study was carried out in the pediatrics unit of a university hospital in the state of Sao Paulo considered a reference for the treatment of chronic diseases.

\section{Participants of the study}

A total of 30 children and adolescents hospitalized between March and December 2016, aged between 7 and 17 years old, of both genders and with a hospital stay of five days or more participated in the study. We chose to include participants in this age group because they are in a phase of human development in which they are able to talk about their experiences and needs ${ }^{(1-4)}$, contributing to the understanding of the studied phenomenon. Children and adolescents unable to establish communication to answer the interview questions, according to the assessment of the nursing team, were excluded. Two participants refuse to participate, without justifying their decision.

\section{Data collection and organization}

For data collection, we chose the semi-structured interview mediated by drawing, which was used to initiate the approach, that is, as a facilitating element. However, it was verified, in the first interviews, that although the drawing favored motivation and initial dialogue of the participants with the main researcher, it was not sufficient for them to answer the questions in a broader way, contributing to the reach of the study objective, since the answers were mostly brief.

For this reason, in the second month of study, precisely in the sixth interview, the main researcher participated in hospital recreation activities, in order to strengthen the bond with the participants. In addition, she made her personal cell phone available for them to choose some drawings they would like to paint, which were printed and distributed by the unit psychology/pedagogy.

It should be noted that the participation of the researcher in the activities was essential, as it favored the construction of bonds and, therefore, the data collection on hospitalization. Sometimes, during the activities, participants spontaneously commented on the hospitalization process and its needs. Another strategy used was to identify topics of interest to the participants in order to gradually introduce the guiding questions. In general, this approach was carried out a few days before the interview.

The interviews lasted approximately 30 minutes and were conducted in a private room, with or without companions, as long as they did not give their opinion during the recordings. At this time, participants were also asked to prepare drawings representing what they would like to have in the hospital, describe what they had drawn and discuss the following guiding question: tell me what you would like to have in the hospital. Those who wanted, 23 in total, also had access to their own interviews, so that they could listen to them.

Data collection ended after a total of 30 interviews, when it was observed that the information already revealed, in quantity and intensity, the multiple dimensions of the studied phenomenon ${ }^{(22)}$, and when the repetition of findings was identified, indicating the achievement of the proposed objective ${ }^{(23)}$.

In addition to the interviews, demographic and clinical data were collected from the medical records in order to characterize the study participants.

\section{Data analysis}

Data analysis followed the principles of inductive thematic analysis $^{(24)}$ and took place in six stages: familiarization with the data; identification of initial ideas; generation of initial codes; search for themes; themes review; and preparation of a final report with analysis and interpretation of the themes according to the theoretical framework constituted by the environment, one of the guidelines of the NHP, and by the Environmental Theory, considering the context of the participants and the researcher. This process was carried out by four researchers. The first and fourth authors independently identified the themes, and then gathered to review them, analyze the discrepancies and compare the agreements and consensus. After that, they were certified and validated by the second and third authors (senior authors). The final report presents the results in two dimensions: Elements of the physical environment and material resources; and Elements of comfort and well-being environment.

\section{RESULTS}

Regarding the characteristics of the 30 participants, 21 were aged between 13 and 16 years old; 17 were girls and all of them attended school: 25 were in elementary school and five in high school. The most frequent diagnoses were Neoplasms (7), Cystic Fibrosis (6) and Type 1 Diabetes Mellitus (5). The average number of hospitalizations was 5.5, with a standard deviation of 4.84 . With regard to their cities, 11 were from the same city of the hospital where the data were collected and the others from cities in that region or even from other states. Participants were accompanied by their mothers (25), sisters (2), grandmother (1), grandfather (1) and father (1).

Data analysis revealed two dimensions: Elements of the physical environment and material resources; and Elements of comfort and well-being environment.

\section{Elements of the physical environment and material resources}

In the first category, the interviewees revealed how they idealized the design and physical resources of the hospital, describing the wards, recreation space, cafeteria and the type of food provided. According to them, wards should be large and provide closets for personal items:

[...] there would even be a bigger closet because there are children who stay here longer [...]; they put their belongings on or under the bed. (Sofia B., 11 years old, I.16) 
There should also be a bathroom for the companions inside the wards, as this would allow them to always be close to the patients:

There should be a bathroom for mothers here. There is a bathroom, but it's far away, I wanted a bathroom in the same room as the patients, so that when I needed my mom, she would be close. (Andressa, 12 years old, I.22)

They also suggested changing the color of health professionals' lab coats:

Their clothes [health team coat] could be blue, orange, a cheerful color, not white, white gives me heartburn. (Giovana, 12 years old, I.13)

In their speeches, they expressed the desire for meals to be served in colorful trays, to enhance the presentation of the dishes, which would facilitate acceptance:

[...] For meals, the trays could be more cute, colorful. (Flor de Luz, 15 years old, I.9)

Other suggestions included choosing some ingredients and how to prepare them:

I miss my mom's food; her rice is very tasty. She uses a very good seasoning, I think it's coconut oil, I can't explain it properly, I think it's a fat she puts on rice, then she stirs it, it tastes good, They could prepare food this way here in the hospital. (Andressa, 12 years old, I.22)

If I were the chef, I wouldn't prepare a too dry food. (Dante, 15 years old, I.17)

[...] the bean would be softer, with more flavor, a tastier food so I don't want to leave soon [...]. There is rice, but rice and beans aren't soft here, the meat is not that good, sometimes it is. (Laura Julia, 12 years old, I.30)

In the projected hospital, there should be a place for recreation, with lockers to store school and play materials and this space would work during the day and night, including on weekends:

[...] change the school too, increase it, make it bigger. It's because the afternoon psychotherapist has only one locker, nothing fits in there, the locker is very full, there could be more of them for her to keep things [...]. I would like the school to be opened all the time, at lunchtime, Saturday, Sunday, it could start in the morning, at 7 am until 11 pm. (Joao Galinha, 10 years old, I.28)

I would like the recreation room to be open on weekends for patients, because on the weekend there is nothing to do, it's very hard. In the recreation room there are things like games, activities and games. (Joao, 15 years old, I.24)

Children and adolescents also suggested changes in the hospital design that favor subjectivity and, therefore, the care process. According to them, the environment should be comfortable and guarantee privacy and autonomy, which highlighted the second category.

\section{Elements of comfort and well-being environment.}

To reduce the number of beds, increase the size of the rooms and improve the circulation and interaction of people, a reorganization of the furniture and objects in the wards was suggested:

The room is very small, on one side there are three beds, it even has more space than on the other side of the room which has four beds. It would be good to remove a bed, there would be three beds on both sides. (Bruno A., 14 years old, I.10)

I would like to make the room bigger, because there are times when it gets tight [...], there would have to be more space to walk. (Laura Julia, 12 years old, I.30)

Participants also proposed the purchase of soft, comfortable, and higher density mattresses, in order to get more comfortable and promoting a peaceful sleep:

I would get a more comfortable mattress, a little thicker, this one is very thin, it's not soft, so it's difficult to sleep here. (Kauan, 16 years old, I.6)

Still thinking about providing more sleeping comfort, they recommended replacing the armchair available to the companions by a comfortable bed, next to them:

I think the place for moms to sleep could be a little cozier [...]; there should be a space for the moms to sleep on the child's side. (Sofia $B, 11$ years old, I.16)

I would like to improve the comfort for the companions, because mothers sleep in the chair and it's very bad, they spend too much time in the hospital, and also have to sleep in the chair, they don't sleep well, there could be a bed. (Joao, 15 years old, I.24)

The installation of fans or air conditioning was another suggestion to make the room cool, pleasant and comfortable:

[...] There should be an air conditioning, because nobody can stand being here in the heat. (Bruno A., 14 years old, I.10)

They also suggested paintings in the wards that represented the children's universe, to make the environment more cheerful:

[...] I think the room is very colorless, I would make some very colorful drawings, some balloons, a rainbow on this wall of the room [...]. I would do it [the floor] like this, very colorful, white with some spots of blue, orange, green, red [...]. I would change this ceiling, I think one with spots like the floor would be nice, because this one makes me sad [...], a non-white room, because white gives me heartburn. (Giovana, 12 years old, I.13)

The room would be a happier, more colorful place [...]; people, drawings on the walls, drawings of flower, butterfly, stars, hearts, trees, apples, everything colorful; very beautiful, with glitters, very colorful for children. (Flor de Luz, 15 years old, I.9)

[...] a fan to keep the environment cooler. (Aline, 13 years old, I.5)

And open visits to friends and family: 
[...] they should at least let five visitors enter here, only one [visit] of them can be here, and the others have to wait downstairs. (Dante, 13 years old, I.17)

If they could let everyone in, it would alleviate the sadness. (Artur B., 11 years old, l.15)

According to them, the distance of family and friends could be reduced by using computers that provide Internet access. This would also allow distraction while on treatment and hospitalization:

As I am at an age that are connected with cell phones all the time, I think the Wi-Fi should be released. As I live far away, I talk to my family over the internet, so I always have to have my own internet on my cell phone, and it's very expensive, so I think Wi-Fi would be good. (Raquel, 16 years old, I.23)

[...] a computer to watch videos on Youtube, chat on Facebook, whats app, so I can be distracted. (Laura Julia, 12 years old, I.30)

Those who had venous access reported the need for a water dispenser inside the rooms, because of their mobility difficulties and the benefit of becoming more independent:

I wish there was a water dispenser here in the room, because I am on IV and I can't go outside, so I have to keep asking other people to do so and I don't like asking for help. People help me, but with that pity face, you know? I get angry. They think you are dependent, they look at me with pity. (Bruno A., 14 years old, I.10)

Other ideas included installing key locks on bathroom doors and accommodation in individual suites, as they have a TV and private bathroom:

I take a quick shower so there's no possibility of someone opening the door, because sometimes people want to get in [...], because I don't like when someone gets in suddenly while I'm showering, this has already happened once. (Bruno A., 14 years old, I.10)

There should be a key lock in the bathroom. (Laura Julia, 12 years old, I.30)

Ilike the Renal Therapy Unitroom more [...]. There are a lot of cool things there. We have a bed, a bedroom and a bathroom just for ourselves [...]; there, I can watch the [television] channel I want. I can do what I want. I can take a shower whenever I want. (Raissa, 13 years old, I.14)

Also seeking for more privacy, the participants designed an outdoor space for private conversations with their companions. It would be a place with flowers, trees, children's playground and gym equipment:

There should be a playground in there, because there are many children here, they stay for a year, nine months, a month. So, for me, there should be a park, with a swing, a slide. (Girlande, 13 years old, I.1)

[...] somewhere I could play, to relax, just like squares that have those gym equipment, we could also have those here [...] it would be really cool, because it would be a way to practice some exercise and still breathing fresh air, seeing trees. (Helena, 16 years old, I.29)
They would change the cafeteria into a place not only for food, but for meeting and talking, with enough space for all children and adolescents to eat together:

There could be more tables in the cafeteria because there are not enough sits for everyone. (Jennifer B., 12 years old, I.26)

[...] I would increase the cafeteria to twice its size, it's very tight there, so everyone would be together. (Helena, 16 years old, I.29)

They also said that the communication between nutritionists and users should be more effective, so that they could inform their food preferences and, thus, improve food acceptance:

They [nutritionists] might ask: would you like bread with butter or with ham and mozzarella today? [...]. Giving us something different to eat, because sometimes we get sick of the food here, then we don't want to eat. (Sofia B., 14 years old, I.16)

According to them, it is also necessary to improve communication with the entire health team, so that each person's demands are met individually, especially with regard to answering questions about health conditions:

Doctors should come [to the wards] more, every day come to the rooms, talk, talk more; they [physicians] rarely show up, they [a pediatric resident] come over to examine us, but physicians don't come every day. I would like to ask them to come and talk to the children more about the treatment, about what they are going through [...], explain it correctly, explain why lam not leaving. (Flor de Luz, 15 years old, I.9)

I would ask physicians to clarify things for me, because sometimes I don't know what's going on, sometimes I get nervous and it's nothing. (Sofia C, 8 years old, I.27)

They reported the extreme importance of recreation spaces, as they promote distraction and allow, even for brief moments, that they do not think about hospitalization:

We get distracted with recreation, we paint, cut, do a new activity every day. (Sofia B., 11 years old, I.16)

The school is very nice [...], because they're trying to make us feel not as we were at a hospital, but at home, trying to make we get our routines back, this is really cool. (Helena, 16 years old, I.29)

Another recommendation was the creation of a music room, aiming to distract and alleviate the adverse effects of hospitalization:

Well, Idrew a music room [...].I would like to have someone who teaches how to play instruments and sing some songs. (Diego, 15 years old, I.3)

When I'm sad, I like listening to music to distract myself. (Helena, 16 years old, I.29)

Finally, they highlighted the need to increase the frequency of cleaning bathrooms:

[...] more hygiene in the bathrooms, three or four times a day. (Kauan, 16 years old, I.6) 


\section{DISCUSSION}

At the moment we gave voice to the study participants to express themselves about what they considered important in the hospital environment, making it more welcoming, we faced a challenge to perform data collection. We tried many approaches to conduct the interviews until we find one that made the communication and interaction between the interviewees and the interviewer easier. Thus, we built a rich empirical material, corroborating the argument of some authors ${ }^{(1,3,8,10,12)}$ about the fact that children and adolescents are able to express their experience in the hospital with a wealth of information, through verbal or non-verbal communication. They are also able to express their points of view through questionnaires, interviews, storytelling, drawing or playing. In the case of this study, they provided us with important information for the improvement of health services, contributing to care qualification.

With regard to the hospital environment in the care of children and adolescents, it must provide conditions to meet their biological and emotional needs, so that they can recognize aspects of their daily lives and some of their references in this place.

So, the first reflections on the environment as an element related to health conditions are made by Florence Nightingale. For her, clean air, light, heat, pure water, cleanliness, adequate food and a peaceful environment would not only favor the recovery of sick people, but were essential for people not to get sick ${ }^{(5)}$.

As seen in the reports, the interviewees wished for an environment of comfort, privacy and value for subjectivity, individuality and uniqueness, in addition to providing well-being, according to the Environmental Theory ${ }^{(9)}$, as well as the principles of humanization in health ${ }^{(14)}$ and the hospital environment ${ }^{(15)}$.

Regarding comfortability principles, the idealized hospital would provide it not only for children and adolescents, but for everyone: companion, family, friends and health team. Therefore, wards should provide enough closets to store personal belongings, as well as water dispensers, comfortable beds and mattresses for a peaceful sleep, which is essential to restore physical exhaustion resulting from the hospitalization process, which is an essential need, especially for these people that needs to recover their health ${ }^{(25)}$. There would also be fans and air conditioning, to keep the environment cool and ventilated; the cleanliness would be rigorous and the environment colorful, translated into a welcoming environment.

A study ${ }^{(26)}$ carried out with a total of 55 children attended at three children's hospitals in Ireland revealed a preference for colorful furniture and themes that represented the children's universe, fauna and flora, with geometric shapes windows and furniture. These studies, as identified in this research, concluded that hospital environments needed to be built not only to be appropriate for children, but also respecting their rights to dignity, privacy and family support.

Considering the comfortability principles for companions, the projected wards are in line with the Resolution of the Collegiate Board 50 (RCB 50) ${ }^{(27)}$ and $\mathrm{NHP}^{(14)}$, for guaranteeing the right to the presence of a companion ${ }^{(20)}$ and design a cozy and comfortable space for them to rest beside the bed of the children or adolescents. In addition, the wards would have their own bathrooms for the companions, in order to keep them close to their loved ones, since they are a source of emotional support ${ }^{(1,28)}$, in addition to promoting well-being ${ }^{(10)}$. Moreover, participants expressed the wish that other family members and friends could be present during hospitalization and, thus, suggested open visits, as recommended by the $\mathrm{NHP}^{(14)}$.

Communication with distant friends and family and also with the outside world could be encouraged if the projected institution provided computers and internet access, so that they could talk with friends and rescue, even partially, their routines. This would also allow, in addition to support and distraction, a disconnection from this disease and care environment ${ }^{(12)}$.

The right to privacy of hospitalized children and adolescents is proposed by the Statute of the Child and Adolescent ${ }^{(20)}$ and was also valued in this study, as some participants suggested accommodation in individual suites, with private bathrooms, that could be locked. A research ${ }^{(4)}$ carried out with a total of 130 children in a hospital in Turkey also showed the desire for greater privacy in the hospital environment, since $19.2 \%$ of participants reported a preference for single rooms and $15.4 \%$ for rooms with private bathrooms.

The absence of privacy can cause adverse effects throughout the hospitalization process, for example, depersonalization ${ }^{(11)}$, which implies the incorporation of hospital rules and norms to the detriment of considering particularities and singularities ${ }^{(29)}$. For this reason, health professionals are asked to provide care without violating the privacy of children and adolescents, in order to avoid adverse effects during hospitalization. However, the installation of keys in hospital rooms and bathrooms is controversial, as the Patient Safety Primer prohibits this action, as it understands that it does not offer safety. The document also warns of some unpredictable situations during the care process, such as falls ${ }^{(30)}$, which can aggravate the patients' health status, especially if they are in a locked place, which makes it difficult to provide care. Thus, health professionals should reflect on the subjectivities of each patient and the best way to provide privacy in the hospital environment.

Study participants emphasized the need to establish effective communication with the health team, which is a strong therapeutic tool, capable of helping to cope with stressors from hospitalization $^{(31)}$. Also as a way of stimulating communication, the cafeteria would be bigger, accommodating all children and adolescents and serving a dual purpose: to be a space for meals and for meetings and conversations.

Still according to the reports, food preferences should be considered and meals offered in colorful trays, aiming at favoring the acceptance of diets. These findings are in line with the results of a prospective observational study conducted with a total of 58 children and adolescents between 1 and 16 years old hospitalized in a hospital in Canada. For the interviewees, the preparation of any hospital diet should respect and consider the individualities of each patient and, as far as possible, include foods of their preference, since the disease process can often cause a lack of appetite. The study also showed that the aesthetics of the dish is essential for food acceptance ${ }^{(32)}$.

As noted in the reports, the recreation space would be designed so that everyone could attend and participate in recreational activities, which are essential for hospitalized children and adolescents, as they are tools of great potential to minimize the suffering and 
trauma resulting from the situation experienced, in addition to essential for the motor, emotional, mental and social development of any child ${ }^{(33)}$. Political guidelines ${ }^{(15)}$ recommend that a hospital has adequate space for recreation and leisure activities in pediatric units.

Other health-promoting environments were also included in the projected hospital, such as the music room and outdoor space (solarium). Some studies have shown that music can contribute to a less traumatic hospitalization process for children and adolescents ${ }^{(34)}$, alleviating anxiety ${ }^{(34-35)}$, anguish and fears, while providing beneficial effects of relaxation and tranquility that favor healthy and adaptive coping ${ }^{(33)}$.

Outdoor spaces, with different types of vegetation and leisure area, can promote well-being ${ }^{(15,33)}$, as they favor new friendships, socialization and subjectivity between hospitalized people and the health team. Thus, these spaces can mitigate the adverse effects of hospitalization ${ }^{(36)}$.

Corroborating the results of this study, Researches conducted in hospitals in the United States of America ${ }^{(37)}$ and the Netherlands ${ }^{(10)}$ showed that children and adolescents seek for hospitals that value comfortability, privacy, particularities and subjectivities, attributes similar to those mentioned by the participants of this study. Therefore, cancer treatment centers named Aquario Carioca were built in Rio de Janeiro-RJ, alluding to furniture and equipment with shapes and colors that resemble the seabed, as well as illustrations of reefs, fish, submarines and typical vegetation that make this space attractive, fun and cheerful. This environment, similar to the projected hospital, also advocates privacy, comfortability and the production of subjectivities. A study pointed out that the Aquario Carioca environment can directly interfere in the health/disease process, favoring the restoration of health ${ }^{(13)}$.

Therefore, it is noted that the results of this study help to understand the hospital environment and its implications for the well-being of hospitalized children and adolescents, as they reveal the perspective of those involved. Likewise, they may enhance interventions for the creation of therapeutic environments that promote development, capable of minimizing the adverse effects of hospitalization.

\section{Limitations of the study}

As a limitation of the study, it should be noted that interviews were conducted only with children older than 7 years old, which makes it impossible to have a deeper understanding of the phenomenon studied.

\section{Contributions to the area of nursing, health or public policy}

The reflections about the hospital environment, based on the contributions of children and adolescents, can subsidize public policies aiming to alleviating the trauma eventually caused by hospitalization. Likewise, they can also qualify health care, particularly nursing care, meeting the real needs of hospitalized children and adolescents and their families.

\section{FINAL CONSIDERATIONS}

From the results, we observed that the participants, when designing their own hospitals, advocated a model of care centered on the needs of hospitalized children and adolescents. The suggested changes contemplated not only architectural and material requirements but also modified the hospital environment, so that it valued the care process, subjectivity, privacy, individuality, and autonomy. In summary, the participants designed a space of dual function: place of healing and interactions.

These are important results, which can motivate reflections about care centered on the principles of humanization of health services and, therefore, contribute to the qualification of care, favoring a less traumatic hospitalization process.

\section{FUNDING}

This research was funded by the National Council for Scientific and Technological Development (CNPq), process number 130230/2015-4

\section{REFERENCES}

1. Costa TS, Morais AC. Child hospitalization: child living from graphical representations. J Nurs UFPE on line. 2017;11(suppl 1):358-67. doi: 10.5205/reuol.7995-69931-4-SM.1101sup201715.

2. Gomes ILV, Queiroz MVO, Bezerra LLAAL, Souza NPG. [Hospitalization in the view of children and adolescents: feelings and experiences lived through]. Cogitare Enferm. 2012;17(4):703-9. doi: 10.5380/ce.v17i4.30378 Portuguese.

3. Linder LA, Seitz M. Through their words: sources of bother for hospitalized children and adolescents with cancer. J Pediatr Oncol Nurs. 2017;34(1):51-64. doi: 10.1177/1043454216631308.

4. Boztepe H, Çınar S, Ay A. School-age children's perception of the hospital experience. J Child Health Care. 2017;21(2):162-70. doi: $10.1177 / 1367493517690454$

5. Nightingale F. Notes on nursing: what it is and what it is not. London: Harrison; 1860. 221 p.

6. Nightingale F. Sick nursing and health nursing. Chicago: The International Congress of Charities, Correction and Philanthropy; 1893.

7. Nightingale F. Notes on hospitals. 3rd ed. London: Longman; 1863.

8. Selanders LC. The power of environmental adaptation: Florence Nightingale's original theory for nursing practice. J Holist Nurs. 2010;28(1):81-8. doi: 10.1177/089801019801600213.

9. Medeiros ABA, Enders BC, Lira ALBDC. The Florence Nightingale's environmental theory: a critical analysis. Esc Anna Nery. 2015;19(3):518-24 doi: $10.5935 / 1414-8145.20150069$ 
10. Schalkers I, Dedding CW, Bunders JF. '[I would like] a place to be alone, other than the toilet'-Children's perspectives on paediatric hospital care in the Netherlands. Health Expect. 2015;18(6):2066-78. doi: 10.1111/hex.12174

11. Xavier DM, Gomes GC, Salvador MDS. The family caregiver during the hospitalization of the child: coexisting with rules and routines. Esc Anna Nery. 2014;18(1):68-74. doi: 10.5935/1414-8145.20140010

12. Nicholas DB, Chahauver A. Examining computer use by hospitalized children and youth. J Technol Hum Serv. 2017;35(4):277-91. doi: $10.1080 / 15228835.2017 .1366886$

13. Gomes IP, Collet N, Reis PED. Ambulatório de quimioterapia pediátrica: a experiência no aquário carioca. Texto Contexto Enferm. 2011;20(3):585-91. doi: 10.1590/S0104-07072011000300021

14. Ministério da Saúde (BR). HumanizaSUS: documento base para gestores e trabalhadores do SUS [Internet]. 4a ed. Brasília, DF: Ministério da Saúde; 2010 [cited 2017 Aug 23]. Available from: http://bibliotecadigital.puc-campinas.edu.br/services/e-books/humanizasus_documento_ gestores_trabalhadores_sus.pdf

15. Ministério da Saúde (BR). Ambiência [Internet]. 2a ed. Brasília, DF: Ministério da Saúde; 2010 [cited 2017 Aug 20]. Available from: http:// bvsms.saude.gov.br/bvs/publicacoes/ambiencia_2ed.pdf

16. Fox SE, Levitt $P$, Nelson CA. How the timing and quality of early experiences influence the development of brain architecture. Child Dev. 2010;81(1):28-40. doi:10.1111/j.1467-8624.2009.01380.x

17. Bronfenbrenner U. Bioecologia do desenvolvimento humano: tornando os seres humanos mais humanos. Porto Alegre: Artmed; 2011.

18. Sousa LC, De Vitta A, Lima JM, De Vitta FCF. The act of playing within the hospital context in the vision of the accompanying persons of the hospitalised children. J Human Growth Develop. 2015;25(1):41-9.

19. Leite ACAB, Alvarenga WDA, Machado JR, Luchetta LF, Banca ROL, Sparapani VDC, et al. Children in outpatient follow-up: perspectives of care identified in interviews with puppet. Rev Gaúcha Enferm. 2019;40:e20180103. doi: 10.1590/1983-1447.2019.20180103

20. Presidência da República (BR). Lei no 8.069, de 13 de julho de 1990 (BR) [Internet]. Dispõe sobre o Estatuto da Criança e do Adolescente. 1990 [cited 2017 Aug 30]. Available from: http://www.planalto.gov.br/ccivil_03/leis/L8069.htm

21. Ministério da Saúde (BR). Resolução no 466/2012. Diretrizes e Normas Regulamentadoras de Pesquisa Envolvendo Seres Humanos [Internet]. Brasília, DF: Conselho Nacional de Saúde; 2012 [cited 2017 Aug 29]. Available from: http://bvsms.saude.gov.br/bvs/saudelegis/ cns/2013/res0466_12_12_2012.html.

22. Minayo MCS. [Sampling and saturation in qualitative research: consensuses and controversies]. Rev Pesqui Qual. 2017;5(7):1-12. doi: 10.1080/10376178.2017.1339566 Portuguese.

23. Saunders B, Sim J, Kingstone T, Baker S, Waterfield J, Bartlam B, et al. Saturation in qualitative research: exploring its conceptualization and operationalization. Qual Quant. 2018;52(4):1893-907. doi: 10.1007/s11135-017-0574-8

24. Braun V, Clarke V. Using thematic analysis in psychology. Qual Res Psychol. 2006;3(2):77-101. doi: 10.1191/1478088706qp063oa

25. Bruni O, Brambilla P. Impact of different recommendations on adequacy rate for sleep duration in children. Ital J Pediatr. 2017;43(1):14. doi: 10.1186/s13052-017-0329-0

26. Lambert V, Coad J, Hicks P, Glacken M. Young children's perspectives of ideal physical design features for hospital-built environments. J Child Health Care. 2014;18(1):57-71. doi: 10.1177/1367493512473852

27. Ministério da Saúde (BR). Agência Nacional de Vigilância Sanitária. Resolução RDC nº 50, de 21 de fevereiro de 2002. Dispõe sobre o Regulamento Técnico para planejamento, programação, elaboração e avaliação de projetos físicos de estabelecimentos assistenciais de saúde [Internet]. Diário Oficial da União: República Federativa do Brasil; 2002 [cited 2017 Aug 29]. Seção 1. Available from: http://www. redeblh.fiocruz.br/media/50_02rdc.pdf

28. França JRFDS, Costa SDFGD, Lopes MEL, Nóbrega MMLD, Batista PSDS, Oliveira RCD. Existential experience of children with cancer under palliative care. Rev Bras Enferm. 2018;71(suppl 3):1320-7. doi: 10.1590/0034-7167-2016-0493

29. Imanishi HA, Silva LL. Despersonalização nos hospitais: o estádio do espelho como operador teórico. Rev SBPH [Internet]. 2016 [cited 2017 Nov 10];19(1):41-56. Available from: http://pepsic.bvsalud.org/scielo.php?script=sci_arttext\&pid=S1516-08582016000100004

30. Associação Nacional de Hospitais Privados (BR). Cartilha de segurança do paciente: como você pode contribuir para que a sua saúde e segurança não sejam colocadas em risco no hospital? [Internet]. 2019 [cited 2019 May 8]. Available from: http://www.hbsaude.com.br/site/ ArquivosDiversos/CartilhaSegurancadoPaciente.pdf

31. Sisk BA, Mack JW, Ashworth R, DuBois J. Communication in pediatric oncology: state of the field and research agenda. Pediatr Blood Cancer. 2018;65(1):e26727. doi: 10.1002/pbc.26727.ADDIN

32. Carter LE, Klatchuk N, Sherman K, Thomsen P, Mazurak VC, Brunetwood MK. Barriers to oral food intake for children admitted to hospital. Can J Diet Pract Res. 2019;80(4):195-199. doi: 10.3148/cjdpr-2019-012

33. Falke ANS, Milbrath VM, Freitag VL. Percepción del equipo de enfermería sobre el enfoque lúdico al niño hospitalizado. Cult Cuid. 2018;22(50):12-24. doi: 10.14198/cuid.2018.50.02

34. Ortiz GS, O'Connor T, Carey J, Vella A, Paul A, Rode D, et al. Impact of a child life and music therapy procedural support intervention on parental perception of their child's distress during intravenous placement. Pediatr Emerg Care. 2019;35(7):498-505. doi: 10.1097/ PEC.0000000000001065 
35. Melo GAA, Rodrigues AB, Firmeza MA, Moura Grangeiro AS, Oliveira, PP, Caetano JA. Musical intervention on anxiety and vital parameters of chronic renal patients: a randomized clinical trial. Rev Latino-Am Enferm. 2018;26:e2978. doi: 10.1590/1518-8345.2123.2978

36. Khan MA, Amin NU, Ahmad I, Sajid M, Jan I, Khattak AM, et al. Therapeutic horticulture: influencing psychological responses of surgical patients and their environmental assessment scale. Pak J Agri Sci. 2016;53(2):255-63. doi: 10.21162/PAKJAS/16.2431

37. Lapp, Valerie. The patient's voice: Development of an adolescent hospital quality of care survey (AHQOCS). J Pediatr Nurs. 2019;49:43-50. doi: 10.1016/j.pedn.2019.08.006 